\title{
Organizational Structure and Financial Resource Management of Universities
}

\author{
Lutfun Rasul Saikia, Pallabi Devi
}

\begin{abstract}
Organizational structure refers to the established pattern of relationship among the parts of an organization. Financial management is directly concerned with finance of any organization. For achieving the organizational goals of a university finance is an integral part of management which depends on great deals of institutional policies. The sample of this study comprises of two universities i.e. Gauhati University as state university and Tezpur University as central university. Secondary sources were used as tools for data collection. The result derived indicated that there was a difference between state and central university regarding organizational structure and financial resource management.
\end{abstract}

Keywords: Resource, Financial Management, Organizational Structure.

\section{INTRODUCTION}

Education is an important human activity. Education was born with human civilization and will continue to act as long as civilization exists. Education has been accepted as one of the prime need of every citizen. The Indian constitution is based on the justice and liberty, equality and fraternity as indicated in the preamble of Indian constitution. Democracy, Secularism, elimination of poverty, creation of socialistic pattern of society and national integration are the national goals that our country is proceeding to achieve through education.

Universities are entrusted with the responsibility of making human resources for the nation. In the word of Pandit Jawaharlal Nehru, the first Prime Minister of Independent India, describe university in his word- "A university stands for humanism, for tolerance, for truth. It stands for the onward march of the human race towards ever higher objectives. If our universities discharge their duties adequately, then, it is well with the nation and the people."

The universities have a significant role of creating an individual who is not only knowledgeable in one academic area, but also sensitive to society and surrounding environment for creating peace, harmony and sustainable development.

Universities are important means for providing knowledge for professional growth and development and give more emphasis on development of a "Whole Person". According to Rabindranath Tagore higher education not only provide information but also makes our life harmonious in all aspects.(Singh, D.P. 2015).

Revised Manuscript Received on November 22, 2019

* Correspondence Author

Prof. Lutfun Rasul Saikia, Gauhati University

Pallabi Devi, Research Scholar, Gauhati University
Universities are an organization with teachers, researchers, students, non teaching staff and administrators. Along with all these aspects universities are considered as the nation building institutions. At present in India, there are 851 universities and 41012 colleges. Out of these 851 universities 47 are centrally funded, 383 are state funded, 295 are privately managed, 123 are deemed univerlsities and 3 are belongs to institute of national importance (www.ugc.ac.in). In Assam there are 20 universities and out of these 2 central, 11 state and 7 private universities. (AISHE report, 2017-18).

\section{Concept Of Organizational Structure}

Organizational structure is the act of putting things in working order. Organization means the arrangement, interrelationship, materials, procedures, knowledge and work to be done in any institution. The meaning of organization define, "an organized structure, body or being" or "systematic arrangement for a definite purpose". G. E. Milward said that it is a process of dividing the work into appropriate tasks of grouping such duties in the form of posts of delegation of authority to each post and of appointing qualified staff which are responsible for the work is carried out as planned". (http:/www.wisedomjobs.com)

The root of an organization consists of groups of people. In the words of Tead (1951): “A going organization arises out of a deliberate association of persons describing to accomplish something together, to realize certain defined objective, which as individuals the persons either could not do for themselves or could not do as well". Thus organization involves the people coming together to realized certain objectives.

Every organization has simple or complex structure. It is a tool of management to achieve plans, and as the plan changes, the organizational structure should be responsive. Organizational structure refers to the established pattern of relationship among the parts of an organization. It cannot be seen, but is understood from the actual operation and behaviors of the members in the organization. Organizational structure determines who is the authority, how much power he exercises and over whom and who makes decision concerning the goals and methods. Organizational structure enables the distribution of authority (Suttle), and this distribution is vital in facilitating processes such as delegation and collaboration across network. Organizational structure is also important for evaluating employee's performances and it is employees performances that determine success in terms of how much and how well, efficiency and effectiveness. According to Gonzale, Johnson and Lundy (2006) said that, "A organization's organizational 


\section{Organizational Structure and Financial Resource Management of Universities}

structure determines the rights, responsibilities and obligations of firm owners with respect to each other and to society in general"'.(

An organization is a group of people (two or more) who works together to achieve a group result. The primary formal relationships of an organization are responsibility, authority and accountability. They enable us to bring together for functioning to achieve the organizational objectives. According to Haney (1976) "Organization is a harmonious adjustment of specialized parts for the accomplishment of some common purpose or purposes". Mc Farland (1979) defines, "Organization as an identified group of people contributing their efforts towards the attainment of goals" (Rahman R.S.2018). Organizations are set up in specific ways to accomplish different goals and the structure of an organization can help its progress towards accomplishing these goals. An organization structure deals with the activities such as task allocation, coordination, and supervision which directed towards the achievement of an organization aims. Organizational structure acts as the viewing glass of an organization through which an individual can see their organization and its environment. It should be shaped and implemented for the primary purpose of facilitating the achievement of organizational goals in an efficient manner.

\section{Concept Of Financial Resource Management:}

Financial resource management is the process of taking financial decisions based on the fund collected from different sources of the organizations. It distributed the collected funds from its profit. Financial resource management is an area of an organization which deals with planning, organizing, directing and controlling the financial activities such as procurement and utilization of funds of the organization. Financial management refers to the efficient and effective management of money (fund) in such a manner as to accomplish the objectives of the organization. So the financial management is specialized function of top management. According to Deepika and Maya Rani, "Financial management is the activity of management which is concerned with the planning, procuring and controlling of the firm's financial resources".

(https:/mindmeister.com > financial management)

Financial resource management in higher education has been a very important and complex issue which should be handled in a holistic manner. Higher education is the instrument for economic development along with social transformation. The main subject concerning higher education in India is financial stress. Though, Government has spent a huge amount of money in higher education but it is not sufficient for fulfilling the required needs. Carnegice Commission on higher education (1982) told that higher education system in United States were also facing financial problems and the commission identified the cause and mentioned that rising cost of higher education in USA which creates problems in higher education. Chandrasri, S (2003) said that universities in Sri Lanka were faced lots of problems due to shortage of funds.

The education system in India is considered as a state subject. The financing of all levels of education is largely depends on the State Government and on the centre. Hyderbud,R.L. and Hundekar, S.G. (2005) mentioned that the financing system of Indian higher education was continue in a traditional ways and Government grants were the main funding agencies in Indian universities. Talukdar, D (2010) highlighted in his studies said that central universities received hundred percent grant from the Central Government and State universities received grant from the State Government and other sources for its development. Besides the normal sources of financing in higher education, some other sources of income were - tuition fees, loans and advances from banks, subsidized loans from government etc. Dutta (1969) also mentioned the various sources of finance in Haryana Colleges and these were fees collection, Government grants, funds from governing bodies and other sources like fines, sale of publications etc. Varghese (2005) gave some alternatives for financing higher education and these includes students loans, donations, international co-operation and linkage, entrepreneurial orientation, fees enhancement etc which were some new concept for resource mobilization.

According to Weston and Brigham financial management takes all financial decisions to coordinate individual motives and achieved entrepreneurial goals. Financial management is a vital activity that must be performed in all organizations. Financial management is a part and parcel of a business which is responsible for getting and proper utilization of fund and necessary for efficient operation said Joshep and Massie.

University requires sufficient funds for smooth running all their academic as well as administrative works. A university having good financial position also helps in attracting more funds and assurances. Along with the tuition fees the universities collect funds from the fees and charges i.e. admission fees, examination fees, certificate issue fees, games and sports fees and other related fees from students. Universities also received grants from UGC, ICSSR, and CSIR etc for its developmental works.

\section{Needs And Significant Of The Study:}

An organization is a group of people having two or more people working together to achieve a group result. In the words of Theo Haiman an organizational structure deals with activities such as task allocation, coordination and supervision are directed towards the achievement of organizational aims.

Financial resource management is the core aspect of every university. Educational institutions are facing numerous problems related to finance. The need for efficient financial management arises due to scarcity of resources, inadequacy of funds, limited sources of revenue etc.

In this paper an attempt has been made to review the organizational structure and financial resource management of the universities. This paper calls for adoption of innovative means for resource generation and to study the different organizational structure of state and central universities of Assam. 


\section{OBJECTIVES OF THE PAPER}

The major objectives of this paper are - (i)to study the difference between Gauhati University (GU) and Tezpur University (TU) regarding organizational structure and (ii)To study the difference between GU and TU regarding financial resource management.

\section{METHODOLOGY}

The study is descriptive research in nature and considered as a casual comparative study, a type of interrelationship study as the study aims to compare between central university (TU) and state university (GU) of Assam.

In this study secondary sources of data collection procedure have been used. Regarding organizational structure, the investigator collected Acts, statutes and ordinance of both the universities. For studying financial resource management, the investigator used Annual Accounts of both the universities.

In Assam, there are total 20 universities including central, state and private universities. Among the universities the sample of the study comprises two universities i.e. GU and TU.

\section{ANALYSIS OF THE STUDY}

Organizational structure of Gauhati University:

- There are all total eighteen administrative Officers in Gauhati University. They are - the Chancellor, the Vice Chancellor, Rector, Registrar, Treasurer, Academic Registrar, Controller of Examination, Director of Student's Welfare, University Engineers, Secretary University Classes, Dean of Schools, Director of College Development Council, Librarian, Director of Human Resource Development Institute, Director of Gauhati University press, Chief Medical Officer, Director of IDOL and Director of Institution of Science and Technology.

- According to Gauhati University act, his excellence the Governor of Assam is the Chancellor of the university. His most important powers are with regard to appointment of the Vice Chancellor. He has to select a Vice Chancellor from a group of three persons listed by the Search Committee. The Chancellor has the power to nominate the certain number of persons as members of the court, the executive council and the academic council.

- Gauhati University operates through six main authorities - The Court, The Executive Council, The Academic Council, The Finance Committee, The Selection Committee and the Faculties.

- In GU, The Executive Council is the compact executive body handling with all matters related to academic, administrative and financial nature of the university.

Organization structure of Tezpur University:

- In Tezpur University, there are all total ten administrative Officers which include - the Visitor, the Chancellor, the Vice Chancellor, the Pro Vice Chancellor, the Registrar, the Finance Officer, the
Dean of Schools, the Controller of Examination, the Proctors, and the Librarian.

- According to the Tezpur University act, His Excellence the President of India is the visitor of the university. According to the act, The Governor of Assam is the Chancellor of the university. The visitor appoints the Chancellor and the Vice chancellor.

- Board of Management is the main administrative body of TU along with The Academic Council, The Planning Board, The Finance Committee and The Building Committee.

- The Board of Management is the main executive body which is concern with all matters related to the university.

Organization structure of Gauhati University and Tezpur University:

It can be seen from the above discussion that there is a difference between officers of both the Universities, though there are some officers of equal mark and standard. On the other hand, there is a difference between in decision making bodies of Gauhati University and Tezpur University regarding the total number of members and their composite structure.

A comparative analysis about the organization structure of Gauhati University and Tezpur University has discussed below.

\section{The Visitor:-}

Though Gauhati University is a State University, so there is no place to a visitor, but Tezpur University is a Central University so it has the position of the Visitor who has the right to inspect and have the power to supervise all works of the university.

\section{The Chancellor:-}

In both the Universities, the Governor of Assam is the chancellor of the university. There is no fixed time period for the said post.

\section{The Vice-Chancellor:-}

In Gauhati University, the Vice Chancellor shall be appointed by chancellor on the recommendation of an advisory Board consist of three members. On the other hand in Tezpur University, the Vice-Chancellor shall be appointed by the Visitor from a panel of three persons.

In the case of Gauhati University, the Vice-chancellor holds the office for the period of 5 years and shall be eligible for re-appointment but in Tezpur University the Vice-Chancellor shall hold office for 5 years or until he attains the age of sixty five years, which is earlier and he shall not be eligible for reappointment.

In Gauhati University, the Vice-Chancellor shall be an ex-officio member and chairmen of the Executive Council, the standing Finance Committee, the Construction Committee and of the Academic council. The Vice-Chancellor shall be entrusted with the responsibility of the principal Executive and Academic 


\section{Organizational Structure and Financial Resource Management of Universities}

officer of the university. In Tezpur University, the Vice-Chancellor shall be the ex-officio chairmen of the Board of Management, the Academic Council the Planning Committee, the Finance committee and the Building Committee.

Pro Vice-Chancellor:-

Clauses' (6) of statutes 2, of Tezpur University Act, the university makes provision for the Pro-Vice-Chancellor. But in Gauhati University, there is no provision of the Pro Vice-Chancellor in Gauhati University.

Rector:-

Section 8 (b) of Gauhati University act, makes provision for the post the Rector. But on the other hand three is no provision of the Rector in Tezpur University.

The Registrar:-

The Registrar is such a post which is available in all Universities of India. The Registrar shall be selected by selection committee appointed by the Executive Council in both the university. The Registrar holds the office for a period of 5 years and shall be eligible for re appoint in university.

In Gauhati University, the Registrar shall be the secretary ex-officer of the Court, Executive Council and the Construction Committee. But in Tezpur University, the Registrar shall be appointment by the Board of Management and the Registrar shall be the ex-officio secretary of the Board of Management, Planning Committee, Academic Council, but shall not be considered to be a member of any of these authorities.

Treasurer / Finance officer:-

In both the Universities the duties and responsibilities are same but they were known as two different designation. In Gauhati University the position is known as the Treasurer and in Tezpur University it is known as the Finance officer. Selection committees were select Treasurer/Finance officer in both the Universities.

Section 8 D of the Gauhati University Act 1947, the Treasurer shall be appointed by the Executive council and may be eligible for re appointment. In Tezpur University the Finance officer shall be appointed by the Board of Management on the recommendation of a selection committee.

A comparative analysis of decision making bodies of GU and TU has discussed below-

The Court / the Board of Management:

In GU, the Court is the main executive body which shall meet at list twice in a year. As GU is a state university so most of the ex-officio members of the court consist with the directors from the different departments of the State Government of Assam. On the other hand in TU, the Board of Management is the main executive body and meets once in a year. In TU the Visitor have the power to nominate the members of the board.

The Executive Council:

In GU, section 12 (i) of the GU Act makes the provision to formulate the executive body. The executive council of GU has the power to appoint a finance committee or construction committee in the time of need of the

university. But on the other hand there is no provision of executive council in TU.

The Academic Council:

The academic council is the most important body of all types of universities. The powers and duties are same in all universities which include maintenance the standard of instruction, education and examination, supervision over the academic policies, evaluation or improvement of academic standard etc.

The Finance Committee:

There is no permanent finance committee in GU. On demand of the university, the executive council shall appoint finance committee to give advice on the matters related to finance. But in TU, the finance committee is the principal authority of the university which has their own structure and they formulate annual accounts and financial estimates for the university.

The Selection Committee:

In both the universities, there shall be a provision of formulating different selection committee for appointment of teaching, non teaching and administrative staff.

From the above discussion it is clear that there is a significant different between GU and TU regarding their organizational structure. Talukdar, D (2010) also supported the findings and said that there is always exist a difference between organizational structure of central and state universities. Singh (1978) told that country wise different universities were established by the Central legislature or State legislature of that particular country.

\section{Financial resource management of $G U$ and TU:}

Financial management system is the oxygen for efficient development and growth of a university. The investigator collected all the Annual financial estimates of GU and Annual Accounts of TU in the year 2014-15 to 2016-17 and then analyzed. The results are highlighted below. The investigator study Non plan and Plan budget under XIIth five year plan.

Non plan budget of GU and TU:

Table-1: Total receipts of GU and TU (in percentage)

\begin{tabular}{|c|c|c|c|c|}
\hline Universitie & Total & \multicolumn{3}{|c|}{ Years } \\
\cline { 3 - 5 } & amount of & 201 & $2015-1$ & $2016-1$ \\
& receipts in & $4-15$ & 6 & 7 \\
$2014-15$ to & $(\%)$ & $(\%)$ & $(\%)$ \\
& $\begin{array}{c}2016-17 \text { (in } \\
\text { lacs) }\end{array}$ & & & \\
\hline GU & 63719.42 & 29.3 & 38.42 & 32.23 \\
& 24138.62 & 28.8 & 38.92 & 32.26 \\
\hline TU & & 2 & & \\
\hline
\end{tabular}

It is found from the table- 1 that the total receipts of TU were comparatively higher than GU in two sample years. Among three academic years, in 2015-16 both the universities received highest amount of money as statutory grant, own sources and others. 
Table-2:Receipts from own sources of GU and TU (in percentage)

\begin{tabular}{|c|c|c|c|c|}
\hline Universities & Total & \multicolumn{3}{|c|}{ Years } \\
\cline { 3 - 5 } & amount of & $2014-15$ & $2015-16$ & $2016-17$ \\
& receipts & $(\%)$ & $(\%)$ & $(\%)$ \\
from own & & & \\
sources in & & & \\
& $2014-15$ to & & & \\
& $2016-17$ & & & \\
& (in lacs) & & & \\
\hline GU & 27507.43 & 32.06 & 35.28 & 32.66 \\
\hline TU & 3390.34 & 32.76 & 30.57 & 36.67 \\
\hline
\end{tabular}

From the table-2, it reveals that university own sources are increasing slowly year after year. Under own sources of university different heads are included i.e. academic fees, examination fees, university hall, other fees, income from other properties, press, institutions etc.

Table-3:Total salary components of GU and TU (in percentage)

\begin{tabular}{|c|c|c|c|c|}
\hline Universities & Total salary & \multicolumn{3}{|c|}{ Years } \\
\cline { 3 - 5 } & components & $2014-15$ & $2015-16$ & $2016-17$ \\
& in 2014-15 & $(\%)$ & $(\%)$ & $(\%)$ \\
& $\begin{array}{c}\text { to 2016-17 } \\
\text { (in lacs) }\end{array}$ & & & \\
\hline GU & 44913.17 & $33.97 \%$ & $35.35 \%$ & $30.68 \%$ \\
\hline TU & 12736.34 & $30.31 \%$ & $33.62 \%$ & $36.08 \%$ \\
\hline
\end{tabular}

Total salary components include salary of academic departments, general administration and retirement benefit. From the table-3, it depicts that total salary components of GU were increased in 2014-15 and 2015-16. It also seen from the table- 3 that in TU total salary components was increasing gradually from $30.31 \%$ to $36.08 \%$.

Table-4: Total expenses of GU and TU (in percentage)

\begin{tabular}{|c|c|c|c|c|}
\hline \multirow{2}{*}{$\begin{array}{c}\text { Universitie } \\
\mathrm{s}\end{array}$} & \multirow[b]{2}{*}{$\begin{array}{c}\text { Total } \\
\text { expenses } \\
\text { of GU } \\
\text { and TU } \\
\text { in the } \\
\text { year } \\
2014-15 \\
\text { to } \\
2016-17 \\
\text { (in lacs) }\end{array}$} & \multicolumn{3}{|c|}{ Years } \\
\hline & & $\begin{array}{c}2014-15 \\
(\%)\end{array}$ & $\begin{array}{c}2015-16 \\
(\%)\end{array}$ & $\begin{array}{c}2016-17 \\
(\%)\end{array}$ \\
\hline GU & 66200.65 & 34.65 & 36.26 & 29.09 \\
\hline TU & 35139.37 & 31.80 & 35.60 & 32.61 \\
\hline
\end{tabular}

From the table-4, it was observed that total expenses were swing because of its present demanding needs of the university. Total expenses define total salary components, other expenses and capital expenses of both the universities. Another extra head is included in GU under total expenses and these are new courses, paid seats and self financing courses in some of the departments.

Table-5: Overall revenue and expenditure of GU and TU (in Lacs)

\begin{tabular}{|c|c|c|c|c|c|c|}
\hline \multirow{2}{*}{ Year } & \multicolumn{3}{|c|}{ GU } & \multicolumn{3}{c|}{ TU } \\
\cline { 2 - 7 } & $\begin{array}{c}\text { Total } \\
\text { receipt }\end{array}$ & $\begin{array}{c}\text { Total } \\
\text { expenses }\end{array}$ & $\begin{array}{c}\text { Surplus/ } \\
\text { Deficit }\end{array}$ & $\begin{array}{c}\text { Total } \\
\text { receipt }\end{array}$ & $\begin{array}{c}\text { Total } \\
\text { expenses }\end{array}$ & $\begin{array}{c}\text { Surplus/ } \\
\text { Deficit }\end{array}$ \\
\hline $2014-1$ & 18699.4 & 22940.2 & -4240.7 & 6957.1 & 11172.7 & -4215.5 \\
5 & 9 & 5 & 6 & 6 & 1 & 5 \\
\hline $2015-1$ & 24481.6 & 24001.6 & 480.05 & 9394.3 & 12508.3 & -3113.9 \\
6 & 5 & 0 & & 8 & 7 & 9 \\
\hline $2016-1$ & 20538.2 & 19258.8 & 1279.48 & 7787.0 & 11458.2 & -3671.2 \\
7 & 8 & 0 & & 8 & 9 & 1 \\
\hline
\end{tabular}

Table-5, indicates that GU face one deficit budget where as in TU all accounting years have deficit budget. Plan budget of GU and TU:

Table-6:Grant received from UGC under XIIth five year plan

\begin{tabular}{|c|c|c|}
\hline \multirow{2}{*}{ Grant } & \multicolumn{2}{|c|}{ Amounts(lacs) } \\
\cline { 2 - 3 } & GU & TU \\
\hline $\begin{array}{c}\text { Development assistance } \\
\text { schemes }\end{array}$ & 1701.00 & 14513.00 \\
\hline Additional grant & 120.00 & 909.64 \\
\hline Special assistance grant & 500.00 & 1000.00 \\
\hline Total & 2321.00 & 16422.64 \\
\hline
\end{tabular}

From the table- 6 , it is found that TU received a huge amount of fund as compare to GU in XIIth five year plans. TU received total 16422.64 lacs whereas GU received only 2321.00lacs only.

From the above discussion it can be concluded that there exist some differences between GU and TU regarding financial resource management.

\section{FINDINGS OF THE STUDY}

On the basis of the analysis of the data the findings related to organizational structure and financial resource management are given below-

\section{Organizational structure}

As GU is a state university and TU is a central university so definitely organizational structure are differ from one another. In GU, most of the powers are concern with the State Government. Under GU there are total 46 post graduate departments, one institute of open and distance learning and one Law College under its premises and 304 numbers of colleges offering graduate and post graduate courses under the affiliation of GU.

TU is a residential central university with 20 numbers of academic departments and one Law College, 7 numbers of centre for Assamese studies, endangered inclusive language, development, 


\section{Organizational Structure and Financial Resource Management of Universities}

teaching learning centre, women studies and centre for innovation incubation and entrepreneurship along with 8 numbers of cells are existed. TU doesn't have the power to affiliate colleges. UGC and MHRD are directly control TU and their activities.

There exists some similarities among the officers of both the universities but there exists some differences between decision making bodies, total number of members presented in different committees and their structure.

It is found that in GU there is no place to a Visitor whereas in TU, Visitor takes an important place and has the power to supervise all activities of the university.

The Governor of Assam is the Chancellor of both the universities and their duties and powers are same in both the universities. Regarding appointment of the Vice Chancellor, the Chancellor of GU recommended an advisory board consist of three persons. On the other hand, in TU, the Visitor formulated a panel of three persons for appointment of the Vice Chancellor. In TU, there exist an administrative officer which is known as the Pro Vice Chancellor but it is not found in GU. There exists a designation name the Rector which is available only in GU. The Registrar is common in all types of universities and ex-officio member of the Court in GU and the Board of Management in TU. The Finance officer is the principal body of all financial matters of a university and without it proper utilization and implementation of funds are not possible. In both the universities the finance officer is known as two different designations but their duties and powers are same. They look after all the funds and their proper utilization for proper development of a university.

Regarding decision making bodies, the investigator found that five bodies are responsible in both the universities. Among these the principal executive body in GU is The Court whereas in TU it is known as Board of Management. The investigator found that in GU, there is no separate finance committee to look after all the financial matters. It is the duty of the Executive council in GU who formulates a finance committee to sort out the matters related to finance. Khan (2003) also said that in central and state universities decision making bodies are responsible for top management of every university.

\section{Financial resource management}

It is seen from the above discussion that GU received highest amount of total receipts, from university's own sources, salary components as well as highest total expenses than TU in three accounting years. GU was established in 1948 and today it has a huge manpower in academic section as well as administrative section. TU was established in 2003 with 20 academic departments with sufficient administrative staff. To maintain the huge manpower GU needs lots of money for giving the salary of all teaching, non teaching and academic staff of the university.

Regarding plan budget, the Central Government takes 100 percentage responsibilities in all sides development of the TU as it is a central university. In XIIth five year plan TU received total 16422.64 lacs of rupees where as GU received only 2321.00 lacs of rupees which are very less as compared to TU.

\section{CONCLUSION}

In order to create world class universities, India must learn from developed countries such as China, Japan, USA etc. To become a world class university, first it must define and prioritize the needs clearly and then must concentrate on those needs. In addition to this autonomous governance is also an essential aspect of World Class University. Too much dependent on government funds and political interference were act as a barrier for many Indian Institutions.

In $21^{\text {st }}$ century, growth of a nation mainly depends on development of science and technology, use of modern innovative methods and techniques, practical knowledge etc. To achieve this objective our research activity should be scientific and must maintain an international standard.

From ancient time, university is the only one means to achieve higher education for example- Nalanda, Taxasila etc. Institution wise the structure of organizational structure is differ from one another. This paper reveals that there is a difference between GU and TU regarding organizational structure. Both the universities have almost similar administrative staff with their common functions and powers. Staff alone cannot work properly if there are no separate decision making bodies for proper execution of work. For effective administration power should be properly distributed through delegation of authority. Smooth running of a university needs transparency and healthy relationship among all members of a university.

All recurring and non recurring grants that are sanctioned by the Government and nongovernmental organizations for maintenance, expansion and improvement the standard of education is known as educational finance. From the investigator's point of view, GU received highest amount of money in different heads like- total receipts, university own sources etc. It is also found that total expenses of GU are higher than TU.

Government financing and resource generations are more important for smooth financing of universities. The government always should inspire the institutions to develop their own capabilities and use creative methods of financing which are fit for the institution and locality.

It was found that most of the universities a large amount of total revenue was absorbed in providing salaries of academic and administrative staff. So from the investigator's point of view it is recommended that excessive human resource should be eliminated by using modern technologies and the rest of money should be used in developmental works of the universities.

\section{REFERENCES}

1. Aggarwal,S.N. (2000) "School Organization, Administration and Management", New Delhi: Doaba House.

2. AISHR Report, 2017-18.

3. Carnegice Commission on Higher Education 1982

4. Chandrasri, S (2003) "Financing of University Education in Srilanka", $\mathrm{PhD}$ thesis, University of Colombo.

5. Gonzale,Johnson and Lundy, (2006) Social capital and organizational structure in Colombian enterprises Research Workshop on collective Action and market access for smallholders, 2-5 oct., Colombia. 
6. Hyderabad R.L. and Hundekar, S.G.(2005) "Financing the higher education in India: Challenges and strategies", University news, 42(52), Dec.27-Jan. 02.

7. https:/ www.mindmeister.com>financial management

8. https:/ www.wisedomjobs.com

9. https:/ www.scribed.com > definition of Financial Management.docx.

10. Mukharji, S.N.(1962) “Administration of Education in India", Baroda: Acharya Book Depot.

11. Sarkar, Rezaur. Rahman (2018) "Organizational commitment of college teachers in relation to occupational stress and job burnout", $\mathrm{PhD}$ thesis, Gauhati University.

12. Singh, D.P.(2015) "Promoting Holistic Education for Individual and Institutional Excellence", University News 53(20), May18-24.

13. The Gauhati University Act 1947, Statutes and Ordinance, Gauhati University Press, Gawahati.

14. The Tezpur University Act 2003, Statutes and Ordinance, Tezpur University , Tezpur

15. Talukdar, Dipankar.(2010) "University administration in North East India with special reference to Gauhati University and North East Hill University", Thesis - Gauhati University of Guwahati.

16. Weston and Brigham (1992) "Essentials of Managerial Finance", $10^{\text {th }}$ edition, Fort Worth :Dryden Press, also see in https:/trove.nla.gov.au/work/8901618.

17. www.ugc.ac.in

18. www.yourarticlelibrary.com $>$ organization: meaning, definition, concept and characteristics.

19. Ibid 